\title{
An Empirical Study of Nigeria's Built Heritage: The Lagos National Arts Theatre and Stadium
}

\author{
Onwuanyi, N. ${ }^{1}{ }^{*}$, Oyetunji, A.K. ${ }^{1}$ and Ogungbenro, M.T. ${ }^{2}$ \\ ${ }^{1}$ Department of Estate Management, University of Benin, Benin City, Nigeria \\ ${ }^{2}$ Department of Estate Management, Federal Polytechnic, Idah, Kogi State, Nigeria \\ Corresponding Author: *ndubisi.onwuanyi@uniben.edu
}

\begin{abstract}
Recognition of built heritage and its preservation are issues of importance to communities and nations for reasons such as learning, identity, tourism among others. However, knowledge of what constitutes built heritage is essential if it is to be properly assessed. This paper investigates what qualities define built heritage in Nigeria using as case studies two well-known national assets: the National Stadium and National Arts Theatre in Lagos. Empirical data for the study are obtained from both physical inspection and public opinion. A survey questionnaire was purposely administered on randomly selected patrons of each of the facilities. Findings are that the two facilities possess significance as built heritage, but are neglected, moribund and not officially so acknowledged. Given plans to dispose of, rather than restore and preserve these facilities, the paper highlights heritage consciousness by drawing attention to the nature and defining characteristics of Nigeria's built heritage, the utter neglect of these two examples and the need to reverse the situation. The nexus between built heritage and the built environment is highlighted as further justification for restoring these assets being important components of the built environment of Lagos and, therefore, the built heritage of Nigeria.
\end{abstract}

Keywords: Nigeria's built heritage, Built environment Significance, Neglect and restoration, Built heritage management

\subsection{Introduction}

It is the practice for nations, societies and cultures which are heritage conscious to accord recognition to, and ensure the preservation of, the finest, remarkable and memorable achievements of their evolution. Heritage consciousness is a pre-requisite for heritage conservation. Heritage resources usually come in three forms: the natural (environmental), man-made (built) and cultural (mores, life-style, tradition and art), of which the first and third further consist of tangible and intangible elements. Built heritage, the man-made, physical evidence of human advancement plays the important roles of giving meaning and depth to a people's narrative, in connecting and unifying people, in giving a sense of place and identity, in imparting knowledge, promoting cultural appreciation and supporting tourism. The many roles of built heritage are reflected in the multi-disciplinary nature of heritage studies which encompasses archaeology, architecture, building, history, conservation, art, economics, engineering, surveying and planning.

According to Modern Heritage Matters (2013), "Built heritage consists of all aspects of the man-made historic environment such as houses, factories, commercial buildings, places of worship, cemeteries, monuments and built infrastructure such as roads, railways and bridges; physically created places such as gardens, mining sites and stock routes; and other places of historical significance such as archaeological sites". What constitutes built heritage may vary according to individual or group perceptions as to what is important, but what remains unchanged is the value attached by the individual or group to that which has been so defined and categorized. Built heritage is basically historic heritage. Therefore, they would all tend to have an historical significance. However, they may also be architecturally and culturally significant. 
The Historic Preservation Commission of Maryland (1996) sets down evaluation criteria for historic built heritage resources as follows: First, cultural and historic significance indicates that the historic resource has/is: "(i) significant character, interest or value as part of the development, heritage or cultural characteristics of the County, State or Nation (ii) the site of a significant historic event (iii) identified with a person or a group of persons who influenced society (iv) exemplifies the cultural, economic, industrial, social, political or historical heritage of the County and its urban and rural communities". Second, architectural and design significance implies that the resource "(i) embodies the distinctive characteristics of a type, period or method of construction.(ii) represents the work of a master craftsman, architect or building.(iii) possesses high artistic values.(iv) represents a significant and distinguishable entity whose components may lack individual distinction (v) represents an established and familiar visual feature of the neighborhood, community or County due to its singular physical characteristics or landscape".

The Mortgage Group (2016) defines architectural significance as "a measure of the impact or importance of a building. The functional or aesthetic design of the building, and/or the methods used to construct the building can all add or detract from a building's architectural significance" whilst ICOMOS sees cultural significance in the "aesthetic, historic, scientific, social or spiritual value for past, present or future generations". Significance, generally, is defined by Historic England (2016) as "The value of a heritage asset to this and future generations because of its heritage interest. That interest may be archaeological, architectural, artistic or historic. Significance derives not only from a heritage asset's physical presence, but also from its setting."

This paper investigates what qualities define built heritage in Nigeria using as case studies two prominent national assets: the National Stadium and National Arts Theatre in Lagos. The thesis of the paper is that these two assets appear to possess the features of historic heritage and may possibly be of significance, their present state invites an enquiry as to what constitutes built heritage to Nigerians. To achieve this objective, the study undertakes a sample survey of members of the public who have knowledge of these facilities in order to ascertain heritage status and the perceived causes of official neglect. The paper also analyses the apparently low level of heritage consciousness in official circles and the need for policy measures for built heritage management and heritage studies generally.

\subsection{Nigeria's Built Heritage}

In countries where best practice is well-established, heritage management is guided by appropriate legislative and administrative arrangements. In England, for instance, heritage issues are handled by English Heritage; in Scotland by Scottish Heritage; in New Zealand by the Department of Conservation; in Australia by the Office of Environment and Heritage. Best practice ensures proper identification, assessment for significance, listing, preservation, protection and enhancement. There is not at present in Nigeria any agency specifically charged with the management of built heritage. The closest agency is the National Commission for Museums and Monuments (NCMM), which by its nomenclature appears to be more of a museum and artifacts body.

The NCMM Act (1990) states that the NCMM's functions are: to administer national museums, antiquities and monuments; to establish and maintain national museums and other outlets for, or in connection with, but not restricted to: antiquities, science and technology, warfare, African, Black and other antiquities, arts and crafts, architecture, natural history and educational services. The commission has seen to the preservation of old colonial buildings, relics and memorabilia, and it has a list of old architectural structures such as the 130-year-old prefabricated red pinewood building in Calabar, the first seat of colonial government in Nigeria. However, the fact that NCMM does not have on its list the National Stadium and National Arts Theatre, the subjects of this investigation, suggests that it is not a built heritage agency or its own definition of built heritage, if indeed it has one, is either inappropriate or narrow.

The National Stadium and National Arts Theatre are major investments made respectively in 1972 and 1976. The two structures are very important components of the built environment of the Lagos Metropolis and have so been for 44 and 40 years respectively. Given that in age terms both structures exceed the span of a generation, they can be regarded as the inheritance of the present generation from the preceding one. 
In other words, the stadium and the theatre are the legacy of the generation of the 1970s and thus the veritable built heritage of this present generation. Whether these structures will become heritage to the next generation depends on what the present generation would do about them as part of the built environment of today. The neglect of the structures has allowed decay to set in and if this is not checked and reversed the result would be a blighted and depreciated environment.

\subsection{The National Stadium}

Nigeria became an independent country in 1960 and this facility, which was built in 1972, was its first national stadium. It is multi-purpose, consisting of a main bowl, practice pitch, gymnasia, sports halls and other facilities. Originally, it was a 55,000-seater facility, but the capacity was later reduced to 45,000. Given its status in the 1970-80s as the pre-eminent, most equipped and most modern sports facility in the country, it played host to most of the sporting activities of that era. The stadium went into disuse following its being closed down in 2004 after the commissioning of the new Abuja National Stadium for the 2003 8th All-Africa Games.

This development has elicited many comments from the public and the press. For instance, Ezaga (2015) laments that: "It is no longer news that the National Stadium in Surulere, once a glorious edifice and symbol of national pride, is now a dilapidated monument that is symbolic of the widespread rot that has virtually crippled Nigeria in recent years. It just boggles the mind how the arena where Nigeria won her first Africa Cup of Nations title in 1980 in front of a record 85,000 crowd, and where a global star like Iker Casillas once sat on the bench as his compatriot Xavi Hernandez helped Spain to the U-20 world title in 1999, has largely become home to rodents and miscreants".

According to Odegbami, a key member of the 1980 Cup of Nations victorious team, as reported by Eagle online (2016), "Neglecting a facility like the National Stadium, Lagos is the worst thing that can ever happen to us in Nigeria. It's a huge embarrassment to Nigerian sport. There is nothing that we have not said about the stadium, but the government would not listen". Tunde Disu, a former coach of the 1980s and 1990s, as reported also by Eagleonline (2016), describes the stadium in its heyday as a national pride which "was like a shrine where the god of football was worshipped. During those days, all the tribes came to watch players from their clans to cheer them and they didn't want them to lose. Lagos fans don't want to lose, whether tactically or technically. It is only in Lagos that you can get such an atmosphere where players get their supporters from all clans cheering them due to the cosmopolitan nature of the state." These comments evidently encapsulate the cultural and historical value attached to the stadium.

Amongst sports enthusiasts of the 1970s up to 2000, the stadium was a prized national arena, referred to by journalists of the age as "sports city". It has a sentimental attachment to the sporting public and many other Nigerians as the venue of the sad and sudden death (later medically established to be from congestive heart failure), on August $12^{\text {th }}, 1989$, of Sam Okwaraji, a senior team Nigerian player widely acknowledged for his talent and exceptional patriotism, in a match against the Republic of Angola. A statue in memory of this patriot and hero is erected at the main entrance to the stadium. The stadium was also the Venue for the 1973 All-Africa Games, (for which purpose it was built) and in which competition Nigeria came second behind Egypt. Other events of national significance held at the venue include Nigeria's first triumph in the African Cup of Nations in 1980, the 33rd year of the competition since it began in 1957, the final of the 1999 Under-20 World Cup, which was the first FIFA championship ever to hold in Nigeria and the final of the 2000 African Cup of Nations co-hosted with Ghana. 


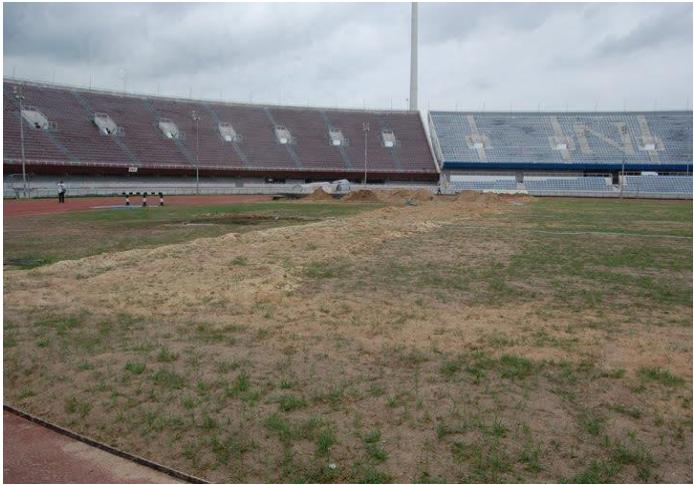

(a)

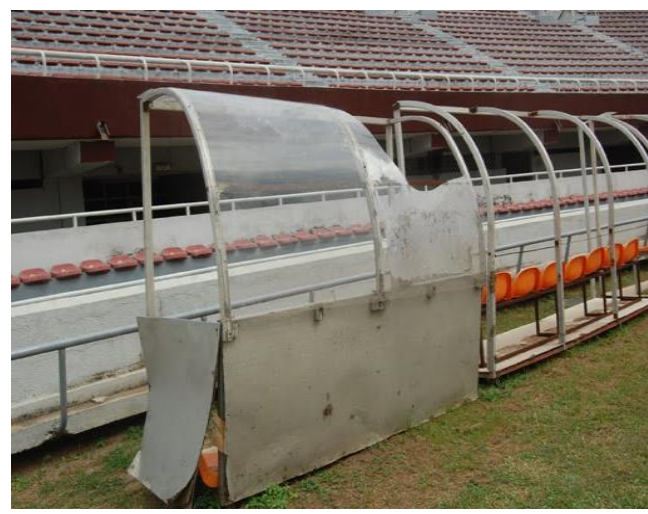

(b)

Figure 1: The National Stadium

\subsection{The National Arts Theatre}

The National Arts Theatre is an iconic structure and arguably still among the most notable of the Lagos landscape. It was built 40 years ago for the dual purpose of the propagation of Nigerian arts and culture and for the hosting of national and international events. Information from the National Arts Theatre website (2015) states that the facility has an area of $23,000 \mathrm{~m}^{2}$ and an elevation of 31 metres, which is equivalent in height to a 7 -storey building.

Nwakunnor et al. (2014) thus report the decline of the theatre: "In the late 1990s, the theatre began to face the agony of poor facilities. The sprawling complex was in darkness due to a lack of electricity supply. The structure was also reported to have been sinking and the roof broken at a time. There was equally a lack of comfortable seats for members of the audience, who pay to watch performances. This gave rise to situations where members of the audience were uncomfortable, or stand all through productions".

These signs of decline were obviously the result of inadequate funding, bureaucratic management and poor maintenance on the part of government, but the official response was to find ways of opting out of any financial commitments to the facility. Government appeared to have forgotten the purpose of the facility which was: "the preservation, presentation and promotion" of the arts and culture of Nigeria (National Arts Theatre website, 2015) when in 2001 a plan for its privatization emerged, followed in 2014 by a business arrangement with a United Arab Emirates organization to convert the facility into a shopping mall and a five-star hotel (Emedolibe, 2015; Mohammed, 2015; Momoh, 2015).

Stakeholders in theatre and the media successfully opposed government's plans immediately they became public knowledge. Momoh's (2015) interview of theatre staff on the controversy over the 2014 government plan either to sell, concession or convert the structure into a shopping mall reveals the regard in which the facility is held by workers and stakeholders. Some of the reactions were: "I think the theatre should be maintained. Other countries are keeping their monuments, like the National Theatre of Ghana. Why do we want to sell ours or turn it into a shopping mall or free trade zone?" "You want to sell a shrine or convert it into a shopping mall. The gods forbid it". The edifice should "be preserved for both historical and cultural reasons and the proposal for its sale is an "attempt to sell the soul of the nation and the Mecca for all performing artistes". These observations indicate that the National Arts Theatre facility means more in every way to the people than it means to the government officials who formulate and execute policy.

This facility is the only national arts and culture centre in the country. It accommodates the National Council of Arts and Culture, Nigeria Gallery of Arts and National Troupe of Nigeria, It was the venue for the $2^{\text {nd }}$ World Black and African Festival of the Arts and Culture held in 1977 "at which participating countries devised a strategy of cultural empowerment... to protect black culture from being destroyed by other cultures and stop it from being seen only in the context of primitive museum artifacts, an event which marked a turning point in the development of a black global consciousness. It enabled artists to 
talk about identity, discuss issues of cultural awakening and think about their collective survival" (Tate, 2015).

In addition, the structure is acknowledged as a Lagos landmark, an architectural success, a national and internationally famous monument for the arts and culture which, in its heyday, was a melting pot for Nigerians who made use of its facilities for a various social activities. As a mark of its status and popularity, it was chosen by United Nations as one of 200 world landmarks, monuments, bridges and statues to be lit-up in blue simultaneously on the $24^{\text {th }}$ of October, 2015 in commemoration of its $70^{\text {th }}$ anniversary.

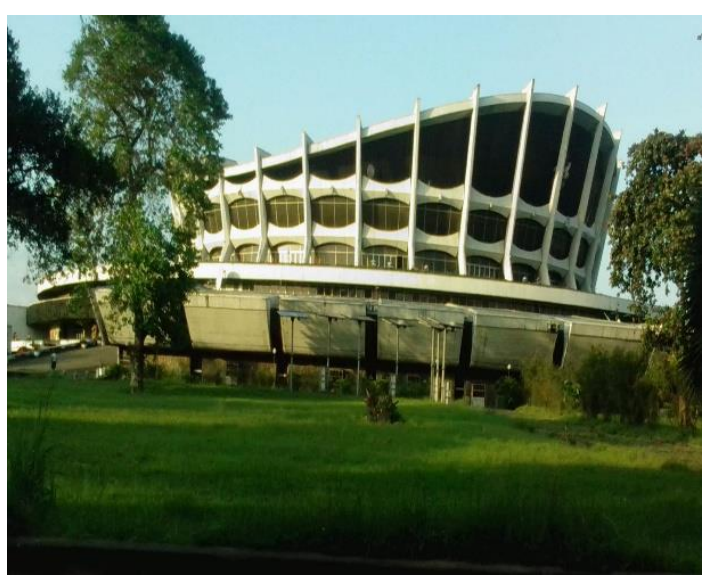

(a)

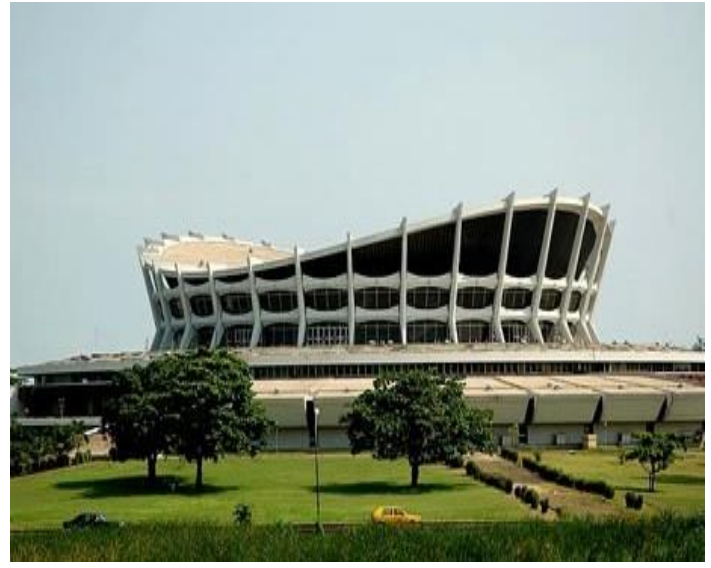

(b)

Figure 2: The National Arts Theatre

\subsection{Materials and Methods}

At the point of embarking upon this study, the authors' impressions were that the subject facilities have attained a level of recognition and historic importance in Nigeria. A pilot study was carried out to gather information on the role and status of these two (2) facilities since their establishment, with a view to corroborate or deny these impressions. The structures and their environments were inspected in October 2015 and assessments made as to their general physical condition. Primary data was collected through physical inspections/field observation, interviews and structured questionnaires with close-ended questions. Secondary data was also collected from public commentary and newspaper reports. A questionnaire was purposely administered on randomly selected patrons of each of the facilities. This was done by investigating a purposive selected sample population of 40 respondents for each facility in 3 consecutive periods (Saturdays for the National Arts Theatre and Sundays for the National Stadium). In total, a sample population of 120 respondents for each facility was obtained, thus giving a total of 240 respondents for both facilities.

\subsection{Results and Discussion}

Table 1 shows the information compiled from the initial study. This information forms the basis of the surveys which were carried out in order to establish how the public regard the facilities. The fact that the facilities date from the previous generation suggests that they are a legacy from the past, and therefore, can be described as heritage assets. The study, therefore, is appropriately an investigation of the neglect of built heritage by evaluating neglect and heritage status respectively through the means of physical inspection of the facilities and questionnaire surveys of selected members of the public who have knowledge of the facilities as well as being end-users. The selection of participants was made from adult persons found on the premises of each of the two facilities, and they consist of visitors, tenants and patrons of the facilities or the businesses located within them. In the case of the National Arts Theatre, the complex is open to the public who daily visit either for sight-seeing tours, the hiring of its halls, visits to the National Gallery of Art, the National Council for Arts and Culture, the Artists' 
Village and those who come to patronize business services provided on its premises by third parties. For the National Stadium, although organized sporting activities are not being held in view of its disused sports infrastructure, the facility is kept open for joggers, sports enthusiasts and businesses which operate on its premises and patrons who hire its sports halls and other available space. The chosen participants already have knowledge of the facilities and their present condition.

Table 1: History of Significance of the Facilities

\begin{tabular}{lll}
\hline Characteristics & National Stadium & National Arts Theatre \\
\hline Year of Development & 1972 & 1976 \\
& $\begin{array}{l}\text { First National Sports Stadium } \\
\text { Venue for 1973 2 } 2^{\text {nd }} \text { All-Africa Games }- \text { Nigeria's } \\
\text { most successful outing as overall second }\end{array}$ & $\begin{array}{l}\text { First National Cultural Facility } \\
\text { Venue for the 1977 2 } 2^{\text {nd }} \text { World Black } \\
\text { and African Festival of the Arts and } \\
\text { Culture }\end{array}$
\end{tabular}

History and Significance Venue of Nigeria's first victory in the African Cup of Nations in 1980 , the $37^{\text {th }}$ year of the competition

A Lagos landmark

Venue for final of the 1999 U-20 World Cup, the An architectural success first FIFA event hosted by Nigeria

$\begin{array}{ll}\begin{array}{l}\text { Venue of } 2000 \text { final of the African Nations Cup co- } \\ \text { hosted with Ghana }\end{array} & \begin{array}{l}\text { Most iconic Lagos structure } \\ \text { arguably to date }\end{array} \\ \begin{array}{l}\text { Most prominent and equipped sports facility in } \\ \text { Nigeria from 1972-2002, very important years for } \\ \text { sports growth and achievement. }\end{array} & \begin{array}{l}\text { Cultural headquarters of country: } \\ \text { home to National Troupe. National } \\ \text { Council for Arts and Culture; } \\ \text { National Gallery of Art. }\end{array}\end{array}$

The approach adopted involved physical inspections to establish the condition of the facilities, preparation of the authors' assessments of the significance of the facilities to the country, survey and weighting of participants' knowledge of the facilities and their state, survey and analyses of participant's perceptions as to the reason for the observed neglect of the facilities, survey and analyses of participants' opinions as to the significance of the facilities to the country and, finally, drawing conclusions as to the significance of the facilities, discussing the implications and making recommendations. Descriptive tools are used in analyses and presentation. The authors' approach of confirming heritage status through a public evaluation is supported by Modern Heritage Studies (2013) which states that "built heritage is defined and categorized according to the needs and values of the person or groups making the definition. Built heritage can be of importance to any one person, group, community, nation or group of nations. There is sometimes agreement in the value of built heritage among many persons or groups, but sometimes values are not shared, and may even be contested". The study was done with the expectation that the results would either confirm or deny the authors' postulation as to significance and that a confirmation would reinforce the argument for the restoration of these public assets.

Observations from the physical inspection as shown in Table 2 reveals that the facilities are not in a good condition and are not cared for. Table 3 shows the analyses of the participants' responses on reasons for the neglect of the facilities. As compiled, the major reason for the neglect of the National Stadium is indisputably government neglect with a mean score ranking of 5.0, while for the National Arts Theatre, government neglect and bureaucratic delays, with a mean score of 5.0 respectively. This implies, therefore that, government neglect is the reason for the present condition of the two facilities. Bureaucratic delays which features prominently in the case of the theatre is also linked to officialdom. 
Table 2: Observations from Physical Inspections

\begin{tabular}{lll}
\hline $\begin{array}{l}\text { Inspected } \\
\text { Area }\end{array}$ & National Stadium & National Arts Theatre \\
\hline Environment & $\begin{array}{l}\text { Unkempt appearance, Poor refuse disposal, Presence of } \\
\text { squatters/artisans, people milling around, poor night } \\
\text { lighting, pot-holed landscaping with broken kerbstones, surroundings } \\
\text { uncut grass, overgrown hedges. }\end{array}$ & $\begin{array}{l}\text { Broken sections in driveway, air of } \\
\text { neglect, poor night lighting, bushy }\end{array}$ \\
Structure & $\begin{array}{l}\text { Damaged sections, stained walls, peeling paint, rusted } \\
\text { metal railing and balustrades, rusted and disused lighting } \\
\text { poles, old/disused fluorescent light fittings }\end{array}$ & Weather bitten façade, roof leaks \\
& $\begin{array}{l}\text { Overgrown pitches, no central electricity supply, no night } \\
\text { Facilities }\end{array}$ & $\begin{array}{l}\text { Unsteady electricity supply, outdated } \\
\text { terrace roofs, old equipment, poorly maintained car park, fund fittings, broken down } \\
\text { tentral air-conditioning }\end{array}$ \\
\hline
\end{tabular}

Table 3: Factors Responsible for Neglect of the Facilities

\begin{tabular}{lcccc}
\hline Factors & \multicolumn{2}{c}{ NATIONAL STADIUM } & \multicolumn{2}{c}{ NATIONAL ARTS THEATRE } \\
& Mean Score & Rank & Mean Score & Rank \\
\hline Government Neglect & 5.00 & 1 & 5.00 & 1 \\
Bureaucratic Delays & 4.33 & 3 & 5.00 & 1 \\
Poor Maintenance & 4.33 & 3 & 4.66 & 3 \\
Poor Planning & 4.66 & 2 & 4.16 & 4 \\
Lack of Funds & 3.33 & 7 & 3.67 & 5 \\
Managerial Incompetence & 3.67 & 6 & 3.67 & 5 \\
Poor Oversight & 4.33 & 3 & 3.67 & 8 \\
Understaffing & 2.66 & 8 & 2.33 & 9 \\
Poor patronage & 1.67 & 9 & 1.33 & 5 \\
\hline
\end{tabular}

Table 4 reveals the respondents assessments on the significance of these facilities. The main reason given for the significance of the National Arts Theatre is that it is known as being a place of national sports glories. This is evident with a mean score of 5.00. It may be inferred from this outcome that participants consider the facility as having an historic significance. However, since sport is also a cultural activity, the facility can be said to be of cultural significance. In the case of the National Arts Theatre, the respondents regard it as having architectural significance .Its successful hosting of the $2^{\text {nd }}$ World Black and African Festival of the Arts and Culture in 1977 and the cultural purpose of the structure each produce a mean score of 5.00. These infer that the facility possesses architectural and cultural significance.

In sum, the results confirm that the neglected National Stadium and National Arts Theatre of Nigeria are significant national real estate assets. Their significance is known to the people of Nigeria, but the present status of the facilities casts doubt as to whether the government of Nigeria is aware of this fact considering where the participants lay the blame for neglect. Additionally, the study shows that participants' assessment of the importance of these facilities to Nigeria serves to confirm that they are heritage structures as the authors earlier postulated. 
Table 4: Assessment of Significance of the Facilities

\begin{tabular}{lcccc}
\hline $\begin{array}{l}\text { Factors responsible for its } \\
\text { Significance }\end{array}$ & \multicolumn{2}{c}{ NATIONAL STADIUM } & \multicolumn{2}{c}{ NATIONAL ARTS THEATRE } \\
& Mean Score & Rank & Mean Score & Rank \\
\hline Earns income for Govt. & 2.00 & 9 & 2.33 & 9 \\
Located in Lagos & 4.66 & 2 & 4.33 & 6 \\
Part of Nigeria's sports history & 4.66 & 2 & Not Applicable & \\
Hosted many national events & 4.66 & 2 & 4.00 & 7 \\
Place of national sports glories & 5.00 & 1 & Not Applicable & \\
Part of Nigeria's cultural history & Not Applicable & & 5.00 & 1 \\
Hosted the Festac in 1977 & Not Applicable & & 5.00 & 1 \\
A famous structure & 4.66 & 2 & 5.00 & 1 \\
A Lagos landmark & 3.00 & 7 & 4.66 & 4 \\
The first National Stadium & 4.66 & 2 & Not Applicable & \\
The first cultural centre & Not Applicable & & 4.66 & 4 \\
Available to the public for hire & 2.66 & 8 & 3.33 & 8 \\
\hline
\end{tabular}

An important question which needs to be addressed in discussing the neglect of these two prominent structures is why they were not officially acknowledged as built heritage and long since given deserved protection. The answers may be found in the following observations.

First, because there is not in existence an agency and appropriate legislation for handling modern built heritage, the concept of built heritage is yet to be rooted. The heritage management offered by the NCMM is concerned mainly with the preservation of artifacts, objects, specimens and cultural monuments.

Second, there is the tendency for built heritage to be conceptualized only in terms of advanced age. There is no gainsaying that built heritage is associated with age being a legacy passed on from generation to generation. However, thinking only in terms of great antiquity is narrow and might explain why it would not occur to the government, most people and even the NCMM to categorize the stadium and theatre as heritage. Built heritage can actually be of modern origins. According to Modern Heritage Matters(2013,ibid), "Today's broader, more inclusive definition of heritage has allowed built heritage of the Modern Era to be recognized for its historic and cultural value. Built heritage of the Modern Era encompasses all types of constructions between 1930 and the mid-1970s. However, built heritage of the Modern Era is often undervalued by the general public and many remarkable buildings built before World War II or immediately after do not appear on official heritage lists".

Third, by its failure to identify heritage value in the two structures the Nigerian state betrays a poor appreciation of history. Evidence for this assertion is found in the incomprehensible replacement of the subject of history with that of civic education in the Nigerian school curriculum. History is heritage, and without history, there cannot be heritage. Without a sense of history, there can be so sense of place. Fourth, a decline in cultural awareness is indicated in the failure to appreciate the value in the two sites. Abandonment of the national cultural centre implies an abandonment of the preservation, presentation and promotion of culture. The plan of the Ministry of Culture and Tourism to dispose of the theatre or give it away in the absence of an alternative suggests that it was not really being alive to its cultural responsibilities.

Fifth, mismanagement has a role in the decisions taken on these facilities by government. The stadium was shut down just after a new one was built in Abuja for the 2003 8th All-Africa Games. It is difficult to justify a new 60,491 -seater stadium for Abuja at a cost of $\$ 360 \mathrm{~m}$ whilst the 55,000-seater located in a more economically viable and significant Lagos was in disrepair and abandonment. In terms of potential patronage, the population of Lagos was then not less than three times that of Abuja, as the 
2006 National Population Census was to confirm subsequently. If the Lagos Stadium was considered to be obsolete, which it was not, it could have been refurbished or rebuilt as was the historic Wembley Stadium in England. Built heritage is as much site as it is place and structure.

Additionally, there is the suspicion, which should not be lightly dispelled, that the Lagos stadium had to be shut down and Abuja's built simply because government officials did not want to be inconvenienced by travelling from Abuja to Lagos for the 8th All-Africa Games, preferring to bring the Games to their own doorsteps regardless of the cost to the country. There is a Nigerian public sector penchant for concentrating all good things in the capital city and regarding things situated outside it as being of less importance. This impression is aided by the fact that virtually all federally-owned, maintained and operated structures comprising offices, secretariats, residential buildings, the National Stadium, the National Arts Theatre, bridges and even roads in Lagos went into a state of neglect after the movement to Abuja on $12^{\text {th }}$ December 1991.

Sixth, that the facilities of this study were not identified officially as built heritage is also attributable to the inadequate capacity in the public sector, where managerial knowledge, exposure, skills and abilities are discernibly lower than in the private sector. Evidence for the poor capacity in the public sector is furnished by Igbuzor (2015) who asserts that "There is no doubt that the Nigerian public sector performance is weak despite increased public expenditure. It has been shown that increased expenditure has not translated into service quality and performance. The missing link is a poor public service delivery process. This is why the way out of the problem is a comprehensive Public Administration Reform to produce a public service that is efficient, effective, transparent and responsive. The public service processes that need reform are planning, policy making, budgeting, human resource management and performance management". The poor state of the public service has been remarked upon also by Asiodu (2012, 2015); Abdullahi (2013) and Abuhere (2015).

Heritage consciousness in our clime tends to be easily understood in terms of cultural heritage resources. Man-made or built heritage, especially of the post-independence era, is less well appreciated in Nigeria. Heritage usually is seen in its ancient and cultural forms, both tangible and intangible. This should explain why, apart from the structures in this study, veritable modern heritage buildings such as the 23storey Independence building (the first high-rise development in Nigeria), the Tafawa Balewa Square (the country's first ceremonial ground at which Nigeria's independence was granted and celebrated) and the 32-storey NET (NECOM) House (once the tallest building in West Africa), have not been categorized as heritage. They are like any other government assets which could be disposed of at any time. In fact, the Tafawa Balewa Square is already under a concession deal, whilst the NET building has been sold. Poor official appreciation of built heritage explains why no effort has been made in more than two decades after the NCMM Act of 1990 either to create a body for the exclusive management of built heritage or to amend the Act to reflect the growing importance of built heritage management and heritage studies.

The built environment comprises "the buildings, structures and associated constructed facilities which make up our various environments. It is the outcome of the choices we make as we continue to manage the earth and exploit its resources (Onwuanyi and Oyetunji, 2016).At any point in time, the built environment consists of what is inherited, what has been created or is being created and what has been re-shaped, which together, comprise what one generation shall leave behind as legacy for its successors. Such legacy, in the form of the structures and sites is what constitutes built heritage.

There is indeed a nexus between built heritage and the built environment. The former is produced by the latter. The built environment of today creates the structures, places and spaces which will ultimately form the legacies of tomorrow. The quality of today's built environment determines the quality of what future generations will receive as built heritage. An unremarkable, unsustainable and nondescript environment will yield built heritage of that ilk. Each generation must not fail to perceive in the built environment its legacy for future generations. The quality of planning, execution and maintenance of the built environment built heritage determines the quality of tomorrow's legacy. Greater appreciation for and the better management of built heritage can bring about a better built environment, and in turn, a legacy of built structures which would be worthy of sustenance. 


\subsection{Conclusion}

This paper investigated the defining qualities of built heritage in Nigeria using as case studies two prominent, but neglected Lagos structures which, in the opinion of the authors, are deserving of recognition as built heritage. The findings confirm that the National Arts Theatre and the National Stadium in Lagos are significant heritage structures which ought to be appropriately categorized as part of Nigeria's built heritage. The following remedial steps are, therefore, recommended.

i. That the two facilities be rescued from their current dilapidated condition, restored to full functionality and thereafter protected as built heritage.

ii. That appropriate legislative, administrative and funding arrangements be made for the management of built heritage in the country.

iii. That official support be given to the development of modern heritage studies in order to provide the intellectual foundation for the preservation of built heritage in the country.

\section{References}

Abdullahi, M. (2013). Ethics and accountability in the Nigerian public service. Academic Journal of Interdisciplinary Studies. 2(5):117-120.

Abuhere, A.I. (2015). Public Service and the future of Nigeria: the way forward (Online) Available at http: //www.nigerianobservernews.com. (Accessed 13 June, 2016).

Asiodu, P. (2012). The public service and the transformation agenda: redefining the rules of engagement. (Online).Available at http://www.nials-nigeria.org. (Accessed on $19^{\text {th }}$ September,2016).

Asiodu, P. (2015). How corruption got into the civil service. (Online).Available at http://www.vanguardngr.com/philp+ asiodu interview. (Accessed 11 August, 2015).

ICOMOS (1999). Burra Charter (Online).Available at http: //www.australia.icomos.org. Accessed 23 December,2016).

Eagleonline (2016). Odegbami and Disu say neglect of national stadium, a national embarrassment. (Online).Available at http: //www.dailytrust.com.ng. (Accessed on $2^{\text {nd }}$ February, 2016)

Emedolibe, N. (2014). National arts theatre not sold, says minister. (Online).Available at http: //www.national mirroronline.net. (Accessed on 7 February,2016).

Ezaga, K. (2015). How npfl can save the dilapidated national stadium, Surulere. (Online). Available at http: //www.thisdaylive.com. (Accessed on July14, 2015).

Historic England (2016). Definition: Significance. (Online).Available at https://historicengland.org.uk/advice/hpg/hpr-definitions/s/536524 (Accessed on 13th September, 2016).

Historic Preservation Commission (1996). Historic and architectural significance: evaluation criteria. (Online) Available at http: // www.pgplanning.org （Accessed on 12 December, 2016)

Igbuzor, O. (2015). Public service quality, administration reform. (Online) Available at http://guardian.ng/sunday-magazine/public-service-quality-administration. (Accessed on 22 March, 2016).

Modern Heritage Matters (2013). What is Built Heritage? (Online). Available at http: //www.modernheritage.com.au. (Accessed 12 November, 2016)

Mohammed, M., (2015). Nigeria abandons plans to sell its famous national theatre. (Online). Africa Review. Available at http: //www.africareview.com (Accessed 12 February, 2016). 
Momoh, H. (2015). Nigeria: Arab money for national arts theatre. (Online)Available at http: //www.allafrica.com. (Accessed on $7^{\text {th }}$ February, 2016).

National Arts Theatre (2015). A national pride (Online).Available at http: //www.nationaltheatreng.org. (Accessed 3 March, 2016).

National Commission for Museums Monuments Act (1990). (Online) Laws of the Federation of Nigeria, Chapter 242. Available at http: //www.nigeria-law.org. (Accessed 4 March, 2016).

Nwakunnor, G.A. Nwanne, C. and Awa, O. (2014). Nigeria: national theatre -how policy inconsistency, negligence starve art house. (Online) The Guardian. Available at http: // www.nigerian guardianews.com (Accessed 10 September, 2016).

Onwuanyi N and Oyetunji A.K (2016): Revitalizing Nigeria's built heritage using fm service delivery: the Lagos national arts theatre complex. International Journal of Sustainable Built Environment, 5, pp579 - 586. http://dx.doi.org/10.1016/j.ijsbe.2016.05.001

Tate (2015). Festac (Second festival of black arts and culture). (Online).Available at http: //www.tate.org.uk. (Accessed 12 December, 2015).

The Mortgage Group (2016). Architectural Significance Definition. (Online).Available at http://www.superbrokers.ca/libra. (Accessed 4 April, 2016) 